\title{
STRUCTURAL AND PHYSICAL PROPERTIES OF REFRACTORY CORDIERITE PRECURSORS PREPARED FROM RICE HUSK SILICA WITH DIFFERENT MgO ADDITION
}

\author{
"SIMON SEMBIRING*, WASINTON SIMANJUNTAK**, RUDY SITUMEANG**, AGUS RIYANTO*, JUNAIDI* \\ **Department of Physics FMIPA, Lampung University, \\ Jl. Prof. Soemantri Brojonegoro No.1 Bandar Lampung, 35145, Indonesia \\ **Department of Chemistry FMIPA, Lampung University, \\ Prof. Soemantri Brojonegoro, No 1 Bandar Lampung, 35145, Indonesia \\ "E-mail: simonsembiring2@gmail.com
}

Submitted November 16, 2017; accepted February 21, 2018

\begin{abstract}
Keywords: Cordierite, Rice husk silica, Composition, Microstructure, Structure
This study describes the structural and physical properties of refractory cordierite prepared from rice husk silica, which is sintered at a temperature of $1230^{\circ} \mathrm{C}$ and followed by the addition of periclace $(\mathrm{MgO})$ from 5 to $30 \%$ by weight. The phases formed and structure changes as a result of periclace addition were investigated using different characterization technique of X-ray diffraction (XRD) coupled with Rietveld analysis, and scanning electron microscopy (SEM). Density, porosity, hardness, bending strength and coefficient of thermal expansion are also measured.

The results obtained revealed that the addition of periclace of 10 to $30 \%$ promoted the transformation of the cordierite to the forsterite and spinel, and the cordierite is practically undetectable. Addition of periclace was found to increase forsterite and decrease spinel. The presence of forsterite and spinel resulted in increased of density, hardness, bending strength, and thermal expansion coefficient, as well as decreased porosity. The coefficient of thermal expansion of the samples with the addition of 10-30\% periclace reach the relatively constant value of $8.2 \times 10^{-6}{ }^{\circ} \mathrm{C}$, with the main crystalline phase is forsterite, followed by spinel in smaller quantities.
\end{abstract}

\section{INTRODUCTION}

Cordierite $\left(2 \mathrm{MgO} \cdot 2 \mathrm{Al}_{2} \mathrm{O}_{3} \cdot 5 \mathrm{SiO}_{2}\right)$ is one of the most potential ceramics in many industrial applications, which is a lot of outstanding properties, such as excellent chemical resistance, thermo-mechanical, thermal shock resistance, low dielectric constant and thermal expansion coefficient [1-5]. Some examples of the application are heat exchangers for gas turbine engines [6], electrical and thermal insulation [7-8], high integral circuits, microchips, [9], display panels [10], and multilayer chip indicators [11]. In recognation of cordierite in various industrial areas, production of cordierite has been continuously investigated and it is found that the cordierite phase formation is strongly dependent on the chemical composition, and the types of raw material. Many investigations have been reported the synthesis of cordierite from a variety of raw materials such as alumina, kaolinite and talcum [12], fumed silica, bauxite, and talcum [13], talcum, kaolinite, fieldspar, and sepiolite [14], stevensite-rich clay and andalusite [15], kaolin, talcum and bauxite [16]. In our previous study [17] solid-state reaction was applied to prepare cordierite from rice husk silica, $\mathrm{Al}_{2} \mathrm{O}_{3}$, and $\mathrm{MgO}$ powders, indicated that $\alpha$-cordierite is dominantly formed at sintering temperature of $1230^{\circ} \mathrm{C}$, while formation of cordierite was achieved at sintering temperature of $1350^{\circ} \mathrm{C}$, using serpertine, kaolinite, and alumina as raw materials [18].

It is necessary to consider in a number of applications where change in crystalline phase can affect physical, termal, stability, integrity, and mechanical properties of cordierite. Significant research has been done, especially focusing on the effects of different additives and their amount of additions during the synthesis of cordierite ceramics on the development of these properties. Several researchers studied the feasibility of fabricating dense cordierite ceramic by reduce or add one of the three oxides $\left(\mathrm{MgO}, \mathrm{Al}_{2} \mathrm{O}_{3}\right.$ and $\left.\mathrm{SiO}_{2}\right)$. For example, Amista, et al., 1995 [19] indicated that the excess component could change the stability ranges of cordierite and reduce the activation. Hwang and $\mathrm{Wu}, 2001$ [20] further concluded that the compositions richer in $\mathrm{MgO}$ than the stoichiometric cordierite compound suppress the formation of $\mu$-cordierite, yet enhance the crystallization of $\alpha$-cordierite, resulting in a higher content of $\alpha$-cordierite. $\mathrm{MgO}$ addition on the cordierite ceramic led to impede the formation of cordierite, as suggested by the formation of forsterite and silimanite phases [19], and also presence of spinel [21], and cristobalite [14]. In addition, the excess $\mathrm{MgO}$ can decrease the melting and 
crystallization temperature [22], and Xiang, et.al [ 23] observed that the increase of $\mathrm{MgO}$ did not obviously reduce the temperature for cordierite crystallisation, but increase the hardness and thermal expansion coefficient. $\mathrm{Al}_{2} \mathrm{O}_{3}$ addition on the cordieite promote crystallisation of cordierite into crystalline spinel, corundum and cristobalite [24]. In contrast, Hwang and $\mathrm{Wu}, 2001$ [20] also obtained that compositions richer in $\mathrm{Al}_{2} \mathrm{O}_{3}$ than the stoichiometric cordierite compound have no effect on the crystallization of $\alpha$-cordierite. Thus, most of the glass crystallizes to $\mu$-cordierite in the initial stage, followed by the slow transformation of $\mu$-cordierite into low content of $\alpha$-cordierite. In previous study [25] synthesize cordierite as the component of refractory material by several of $\mathrm{Al}_{2} \mathrm{O}_{3}$ mole ratio from 2 to 1.4. They found that $\mathrm{Al}_{2} \mathrm{O}_{3}$ mole ratio to 1.4 , resulted in bulk density to reach the maximum value of $2.5 \mathrm{~kg} \cdot \mathrm{m}^{-3}$, which is close to the value for dense cordierite ceramic. Sembiring, et.al [24] found that addition of $15-30 \%$ alumina, resulted thermal expansion coefficient to reach the relatively constant value of $9.5 \times 10^{-6} /{ }^{\circ} \mathrm{C}$, with the main crystalline phase was spinel, accompanied by corundum and cristobalite in smaller quantities. Another study [26] obtained that addition of $10 \%$ alumina resulted in increased porosity and decreased modulus of rupture, while further addition up to $30 \%$ led to decreased dielectric constant.

Rice husk is an agricultural residue abundantly available in rice producing countries. Among the different types of biomass for power generation, rice husk has a high ash content varyng from $18-20 \%$, in which silica is the major constituent with the quantity of $94-98 \%$ [27-28]. With such large silica content in the ash, it becomes economical to extract silica from the ash, which has wide market and also takes care of ash dispossal. In additions to its high purity, rice husk silica exists as excellent and unique properties, such as high surface area, amorphous phase, fine particle size, and high reactive. Many researchers are currently engaged in exploration of rice husk silica potential, and a wide range of its applications has been reported in literatures, such as production of silica nitride, magnesium silicide [29-30], solar grade silicon [31], silicon carbide [32], magnesium-alumina-silica [33], lithium-aluminum-silica [34], cordierite [35], and mullite [36]. In our previous investigations, rice husk silica obtained by simple acid leaching [37-38] has been used to produce several ceramic materials include borosilicate [39], carbosil [40], aluminosilicate [41], mullite [42-43], cordierite $[17,44]$ and forsterite [45].

This current study was aimed to quantify the phases present in the nonstoichiometric on modification of composition, and explore the relationship between composition and physical characteristics of refractory cordierite. The present study is concerned on the effect of $\mathrm{MgO}$ (periclace) content relative to cordierite on the phase transformation, crystallisation and physical characteristics of refractory cordierite prepared from amorphous rice husk silica. To gain insight on several basic characteristics, the crystallisation of refractory cordierite with periclace addition were studied by means of x-ray diffraction (XRD), and microstructural development of refractory cordierite by scanning electron microscopy (SEM) studies. In this study, the phases present was obtained based on its weight percentage using the Rietveld method. In our previous study, the Rietveld method has been succsefully used to quantify the presence of phases in the sample $[17,44]$ because it is considered the most accurate method with no internal standard sample required.

\section{EXPERIMENTAL}

\section{Materials}

Raw husk used as a source of silica was from local rice milling industry in Bandar Lampung Province, Indonesia. Aluminium oxide $\left(\mathrm{Al}_{2} \mathrm{O}_{3}\right)$ and magnesium oxide $(\mathrm{MgO})$ powders with particle size $6.8-8.1 \mu \mathrm{m}$, purity $\geq 98.0 \%, \mathrm{KOH}, \mathrm{HCl}$, and absolute alcohol $\left(\mathrm{C}_{2} \mathrm{H}_{5} \mathrm{OH}\right)$ were purchased from Merck $(\mathrm{kGaA}$, Damstadt, Germany).

\section{Preparation of silica from rice husk}

Rice husk silica was obtained using alkali extraction method following the procedure reported in previous study [43]. $50 \mathrm{~g}$ washed and dried husk was mixed with $500 \mathrm{ml}$ of $5 \% \mathrm{KOH}$ solution and boilled in a beaker glass for 30 minutes. The sol obtained was acidified by dropwise addition of $5 \% \mathrm{HCl}$ solution until conversion of the sol into gel was completed. The gel was oven dried at $110^{\circ} \mathrm{C}$ for eight hours and then ground into powder.

\section{Preparation of cordierite powder}

Preparation of cordierite was carried out by mixing raw materials with the composition of $\mathrm{MgO}: \mathrm{Al}_{2} \mathrm{O}_{3}: \mathrm{SiO}_{2}$ of 2:2:5 by mass, in accordance with the composition of cordierite as reported in previous studies [17]. The raw materials were mixed with alcohol under magnetic stirring for 6 hours, then the mixture was filterred and the solid was oven dried at $110^{\circ} \mathrm{C}$ for eight hours to remove the adsorbed alcohol. The solid was ground into powder by mortar and sieved to obtain the powder with the size of 200 meshes.

\section{Preparation of cordierite-periclace powder}

To obtain the solid cordierite-periclace, calculated quantities of cordierite was added under stirring to the appropriate of periclace to give the ratios of cordierite and periclace as a mass ratio of 100:0, 95:5, 90:10, $85: 15,80: 20,75: 25$ and 70:30. The powder was pressed in a metal die with the pressure of $2 \times 10^{4} \mathrm{~N} \cdot \mathrm{m}^{-2}$ to 
produce cylindrical pellet and the pellets were sintered at temperature of $1230^{\circ} \mathrm{C}$ according to the previously known crystallisation temperature of cordierite [17], using temperature programmed with a heating rate of $3^{\circ} \mathrm{C} \cdot \mathrm{min}^{-1}$ and holding time of 4 hours at peak temperatures.

\section{Characterisation}

The phases presence of the samples were identified out using an automated Shimadzu XD-610 X-ray diffractometer at the National Agency for Nuclear Energy (BATAN), Serpong-Indonesia, operated with $\mathrm{CuK}_{\mathrm{a}}$ radiation $(\lambda=0.15418)$ radiation in the $5^{\circ} \leq 2 q \geq 75^{\circ}$ range, with a step size of 0.02 , counting time $1 \mathrm{~s} /$ step. The X-ray tube was operated at $40 \mathrm{kV}$ and $30 \mathrm{~mA}$, with a $0.15^{\circ}$ receiving slit. The diffraction data were analyzed using JADE software after subtracting the background and stripping the $\mathrm{CuK}_{\mathrm{a} 2}$ pattern [46]. In order to quantify the phases, Rietveld analyses [47] of XRD data were conducted by search-match method [48], and the crystal structure models used in the calculation were collected from the Inorganic Crystal Structure Data Base [49]. Microstructural analysis was conducted with SEM Philips-XL, on polished and thermally etched samples. The examination of porosity and density was done according to Archimedes method [50]. In order to evaluate the mechanical properties of the samples, a Zwick tester was used to measure the Vickers hardness, with three replicate measurements for each

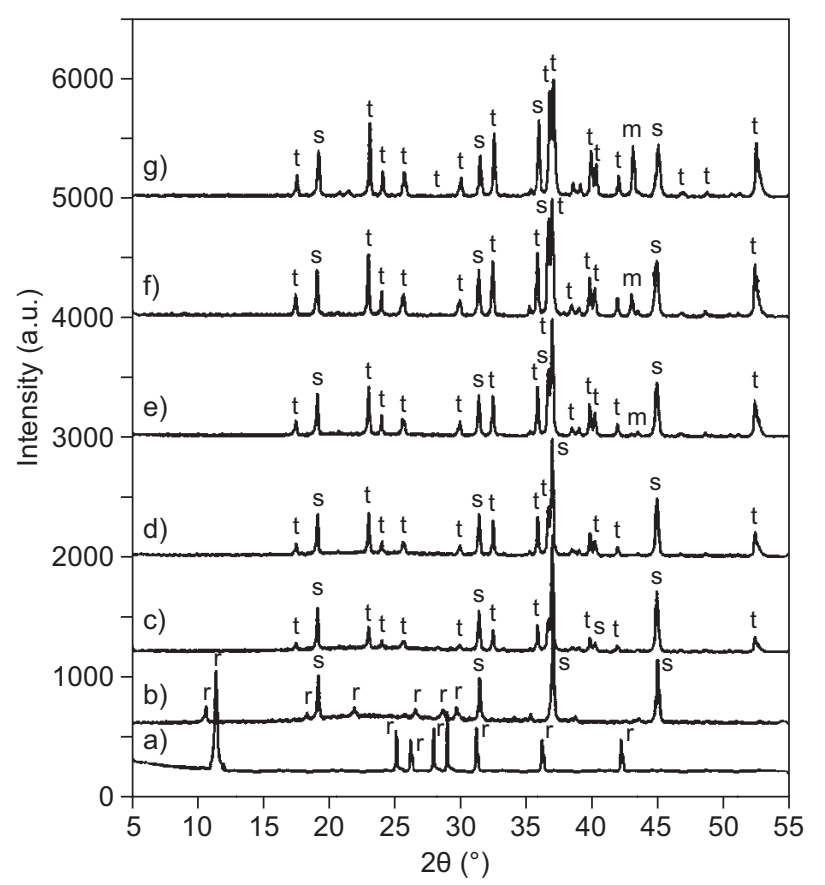

Figure 1. The $\mathrm{x}$-ray diffraction patterns of the sintered samples at temperature of $1230^{\circ} \mathrm{C}$ with different periclace content: a) 5 , b) 10 , c) 15 , d) 20 , e) 25 , and f) $30 \% . r=\alpha$-cordierite, $\mathrm{s}=$ spinel, $\mathrm{m}=$ periclase, $\mathrm{t}=$ forsterite loading position. Bending strength or Modulus Rupture (MOR) was determined by the three-point method following the ASTM C268-70. The measuring of thermal expansion coefficient was conducted using dilatometry (Harrop Dilatometer), in the temperature range of $150-600^{\circ} \mathrm{C}$ at a heating rate of $5^{\circ} \mathrm{C} \cdot \mathrm{min}^{-1}$. The linear thermal expansion coefficient $(\alpha)$ was automatically calculated using the general equation: $\alpha=(\Delta L / L)(1 / \Delta T)$ where: $(\Delta L)$ is the increase in length, $(\Delta T)$ is the temperature interval over which the sample is heated and $(L)$ is the original length of the specimen.

\section{RESULTS AND DISCUSSION}

\section{XRD and Rietveld structural characterisation}

To compare the structure of the modified cordierite obtained using periclace addition, the samples were characterized using XRD. Figure 1 display the XRD patterns of the samples sintered at temperature of $1230^{\circ} \mathrm{C}$ with different periclace addition. By using search-match method [48], the results clearly reveal the presence of $\alpha$-cordierite $/ \mathrm{Mg}_{2} \mathrm{Al}_{4} \mathrm{Si}_{5} \mathrm{O}_{18}$ (PDF-13-0294) with the most intense peak at $2 \theta=10.50^{\circ}$, spinel $/ \mathrm{MgAl}_{2} \mathrm{O}_{4}$ (PDF-2111520 ), at $2 \theta=36.91^{\circ}$, periclase $/ \mathrm{MgO}$ (PDF-45-0946) at $2 \theta=42.91^{\circ}$, and forsterite $/ \mathrm{Mg}_{2} \mathrm{SiO}_{4}$ (PDF-34-0189) $2 \theta=36.55^{\circ}$. The phases identified with the PDF diffraction lines using search-match method are compiled in Table 1 .

According to Table 1, $\alpha$-cordierite as the dominant phase is clearly detected and minor phases were spinel and periclace in the sample without addition of periclase, while spinel is the as major phase with minor phase of cordierite in the sample of $5 \%$ periclace addition. On further increasing periclace content to $10 \%$ (Tab. 1), the $\alpha$-cordierite was totally changed into spinel as major phase with new minor phase of forsterite. In fact, according to Salwa, et.al, 2007 [26] and Li, et.al, 2015 [23], large amount of periclace addition tend to supress and impede the growth of cordierite crystals. With increasing periclace from 15 - $30 \%$ (Table 1) show forsterite as major phase and with minor phases are spinel

Table 1. XRD results of the samples sintered at $1230^{\circ} \mathrm{C}$ with different periclace addition. [ $\alpha$-cordierite (PDF-13-0294), spinel (PDF-21-11520), periclace (PDF-45-0946), forsterite (PDF-34-0189)].

\begin{tabular}{ccc}
\hline Periclace $(\%)$ & Main Phases & Other Phases \\
\hline 0 & cordierite & spinel, periclace \\
5 & spinel & cordierite \\
10 & spinel & forsterite \\
15 & spinel & forsterite \\
20 & forsterite & spinel, periclace \\
25 & forsterite & spinel, periclace \\
30 & forsterite & spinel, periclace \\
\hline
\end{tabular}


and periclace. Overall, a decrease in the $\alpha$-cordierite phase following the increase in periclace content reflects the more intensive augmentation of periclace addition to form forsterite. However, addition of periclase from $5-30 \%$ are found to increase amount of forsterite, while spinel decreased. These findings are in agreement with the result of previous study [9], in which it was suggested that periclace addition is more intensively reactive with $\mathrm{SiO}_{2}$ to form forsterite. The forsterite was formed through interaction of $\mathrm{MgO}_{4}$ and $\mathrm{SiO}_{4}$ [51], and spinel is most likely as a result of interaction between $\mathrm{AlO}_{6}$ and $\mathrm{MgO}_{6}$ octahedral [52]. To verify the XRD results above, Rietveld analysis was used to obtain quantitative information on the phase composition of the samples. As representatives, the refined XRD patterns of the samples sintered at $1230^{\circ} \mathrm{C}$ with the periclace content of 5 and $30 \%$ are presented in Figures 2a-b.

The structural of the best fits and quantitative results (phases concentrations in wt. \%) calculated by the Rietveld method for all samples are depicted in Table 2. The parameters $R_{w p}, R_{\text {exp }}, R_{p}$ and GoF indicate the quality of the fitting. The goodness of fit (GoF) (Tab. 2) values relatively low according to basic principle of GoF, in which the GoF value less than $4 \%$ is conside-

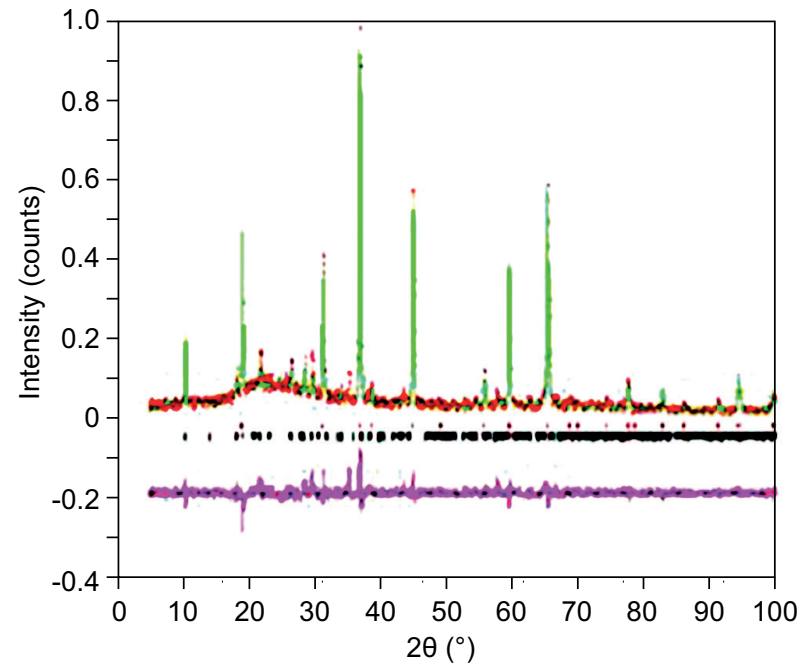

a) $5 \%$ red acceptable [53]. Therefore, perfect agreements were observed between the measured and the calculated patterns.

As shown in Table 2, the amount of cordierite decreased as the periclace content increased from 5 to $30 \%$, suggesting that the phase crystallisation was started by addition of $5 \%$ to produce high amount of spinel and $10 \%$ for forsterite, which implies that more periclace reacted with an alumina and silica to form spinel and forsterite respectively. When the periclace addition is higher than this limit (5\%), the periclace tends to dissolve in the silicate chain to form a forsterite phase and consequently the amount of forsterite continues to increase as the amount of periclace increases. This trend is in agreement with decerased amount of cordierite observed as the amount of periclace increased.

\section{SEM microstructural characterisation}

The surface morphologies of the samples with different periclace contents after subjected to sintering temperature of $1230^{\circ} \mathrm{C}$ were compiled in Figures 3a-f, indicating significant effect of periclace addition on the size and distribution of the particles on the surface.

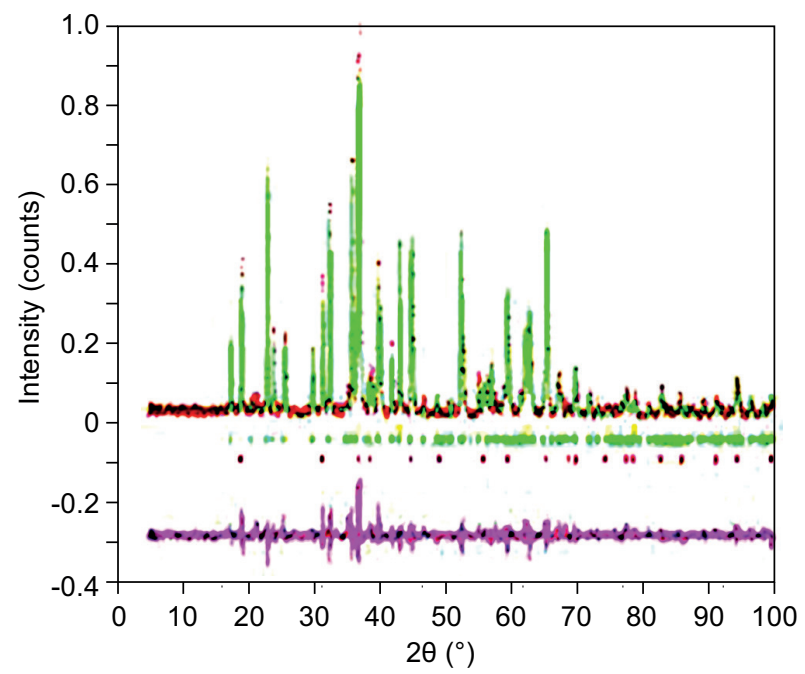

b) $30 \%$

Figure 2. Example of Rietveld plots for the sintered samples at temperature of $1230^{\circ} \mathrm{C}$ with different periclace content: a) $5 \%$ and b) $30 \%$.

Table 1. Figure-of merits (FOMS) and weight percentage (wt. \%) from refinement of XRD data for the samples sintered at $1230^{\circ} \mathrm{C}$ with different periclase addition for $6 \mathrm{~h}$. Estimated errors for the least significant digits are given in parentheses. $[\mathrm{r}=\alpha$-cordierite, $\mathrm{s}=$ spinel, $\mathrm{m}=$ periclase, $\mathrm{t}=$ forsterite $]$

\begin{tabular}{ccccccccc}
\hline $\mathrm{MgO}(\%)$ & $\mathrm{R}_{\text {exp }}$ & $\mathrm{R}_{\mathrm{wp}}$ & $\mathrm{R}_{\mathrm{p}}$ & $\mathrm{GoF}$ & $\mathrm{r}(\mathrm{wt} . \%)$ & $\mathrm{s}(\mathrm{wt.} \%)$ & $\mathrm{m}(\mathrm{wt} . \%)$ & $\mathrm{t}(\mathrm{wt} . \%)$ \\
\hline 0 & 9.52 & 10.25 & 11.56 & 1.21 & $90.5[3]$ & $4.7[4]$ & $4.8[2]$ & - \\
5 & 16.36 & 16.78 & 12.75 & 1.05 & $9.2[4]$ & $90.8[3]$ & - & - \\
10 & 15.69 & 15.86 & 12.04 & 1.02 & - & $64.3[4]$ & - & $35.7[3]$ \\
15 & 15.40 & 17.03 & 12.87 & 1.22 & - & $52.7[5]$ & - & $47.3[2]$ \\
20 & 16.25 & 17.89 & 13.63 & 1.21 & - & $45.1[2]$ & $0.5[3]$ & $54.4[4]$ \\
25 & 15.35 & 17.31 & 17.22 & 1.27 & - & $36.6[4]$ & $3.9[2]$ & $57.5[3]$ \\
30 & 15.65 & 17.32 & 12.84 & 1.22 & - & $30.6[3]$ & $8.9[3]$ & $60.5[4]$ \\
\hline
\end{tabular}




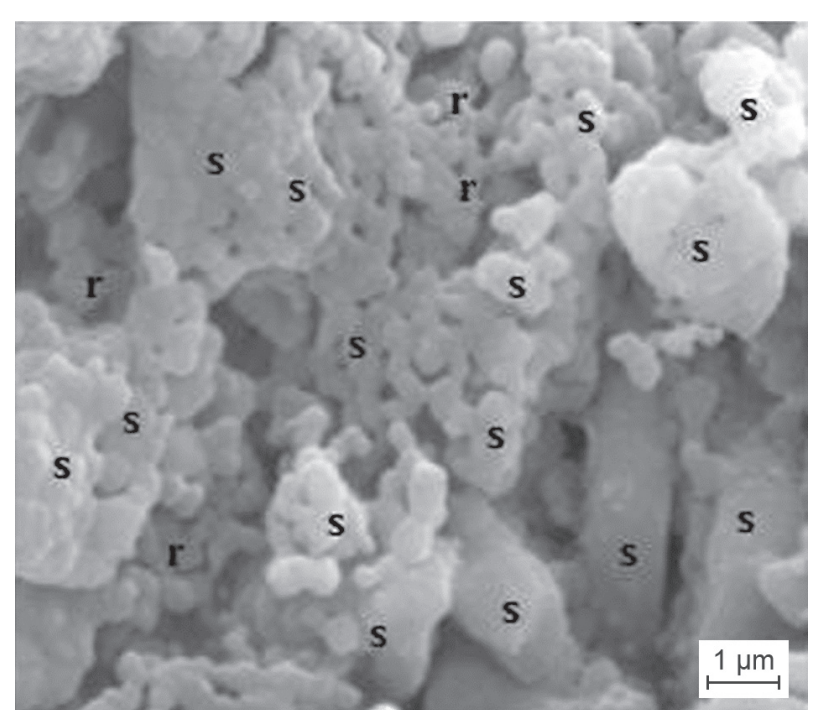

a) $5 \%$

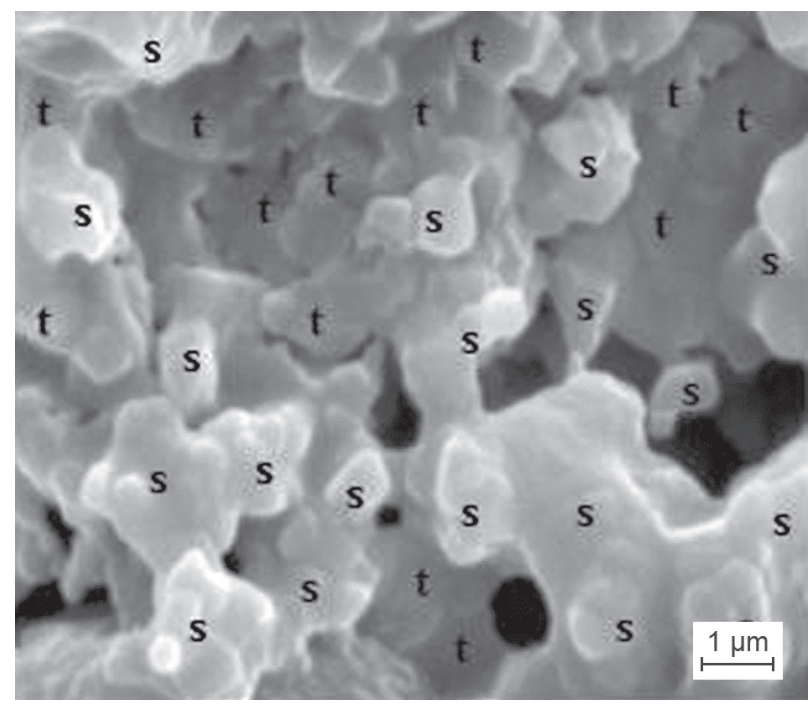

c) $15 \%$

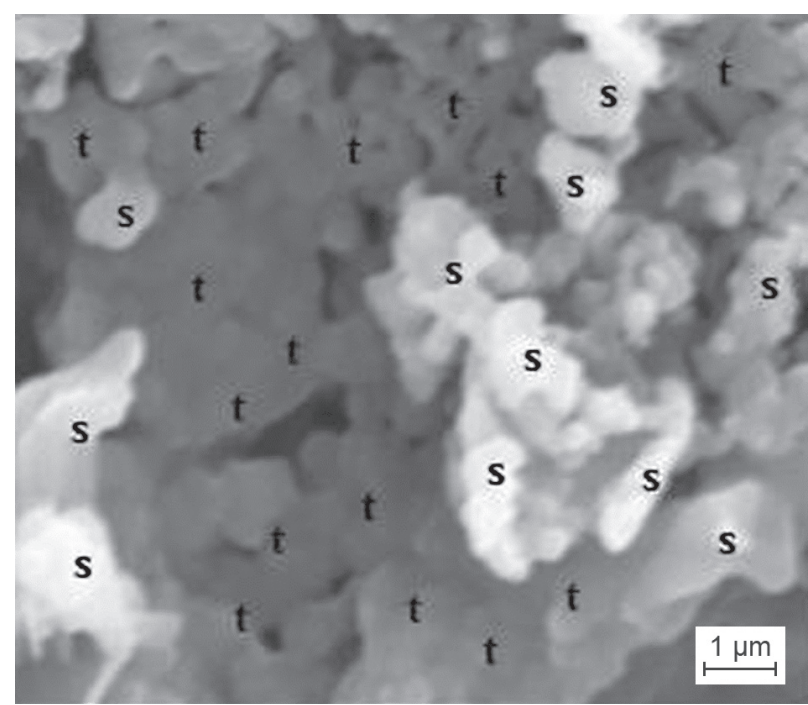

e) $25 \%$

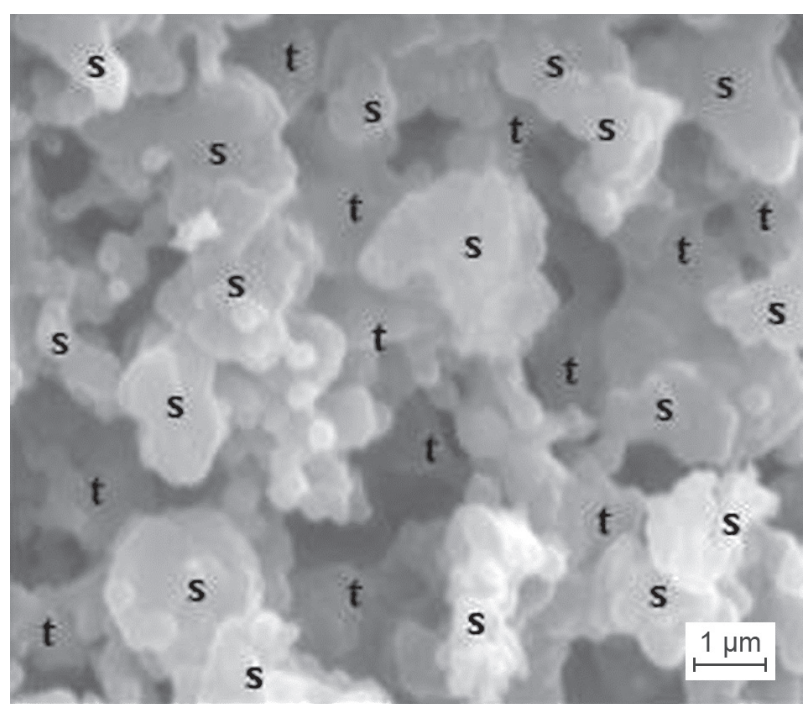

b) $10 \%$

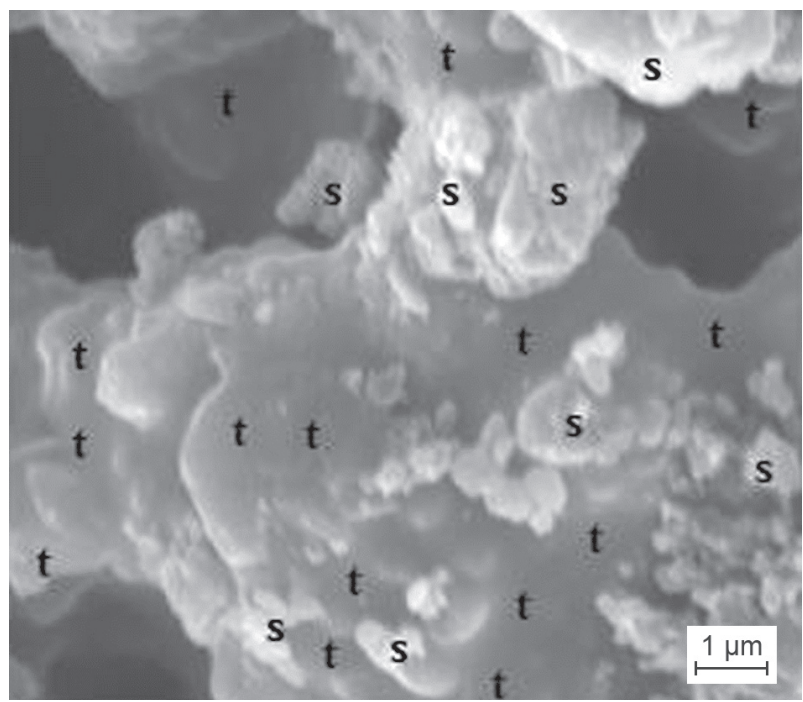

d) $20 \%$

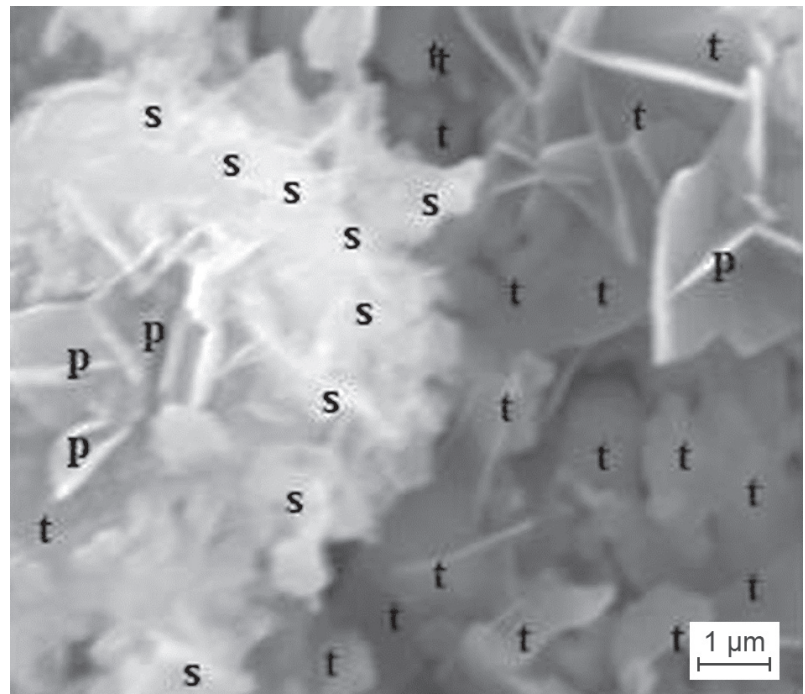

f) $30 \%$

Figure 3. The scanning electron microscopy (SEM) images of the samples sintered at $1230^{\circ} \mathrm{C}$ with different periclace content: a) $5 \%$., b) $10 \%$., c) $15 \%$., d) $20 \%$., e) $25 \%$, and f) $30 \%$. $r=\alpha$-cordierite, $\mathrm{s}=$ spinel, $\mathrm{p}=$ periclase, $\mathrm{t}=$ forsterite 
In our previous study [17], the microstructure of the sample without periclace addition displayed homogeneous grain size with high evident grain boundaries, and small amount of some larger grains of spinel. It is quite different characteristics to those of the samples with 5 and $10 \%$ periclace addition (Figures $3 \mathrm{a}$ and b). With reference to XRD results (Tab. 1 and 2), it is obvious that the sample with $0 \%$ periclace addition is mainly dominated by $\alpha$-cordierite. It is quite clear that the sample containing $5 \%$ periclace exhibits large grains and different sizes on the surface, while $10 \%$ periclace is evident granules dispersing in the surface. This profile may be due to increased viscosity of the glassy matrix as a result of additional periclace, which suppressed the migration of atoms and facilitated the granules connected with each other.

Lower extent of a-cordierite formation was suggested by the SEM micrographs of the samples with $15-30 \%$ periclace content (Figures $3 c-f$ ), which exhibited high agglomeration on the entire surface as the periclace content increased. This high extent of agglomeration led to lower quantity of a-cordierite produced, as indicated by the XRD results (Table 2). This agglomeration phenomenon demonstrated that in the samples with periclace content ranging from $15-30 \%$, the $\alpha$-cordierite has decomposed completely into forsterite and spinel. This demonstrates that increasing periclace can facilitate liquid production. Sufficient liquid wetted the particle surface and made them connect each other as shown in Figures $3 \mathrm{c}-\mathrm{f}$. Comparing Figures $3 \mathrm{a}$ with $\mathrm{b}$ and $\mathrm{c}$, the pores distribution was more nonuniform in Figures $3 b$ and $c$, and there were more dense parts in Figure 3a. This may be the reason that increase of periclace is decreasing the porosity of the samples (Figures 3c-f). As shown in Figures $3 \mathrm{c}-\mathrm{f}$, it is obvious that the porosity decreases with the periclace increasing. Increasing of periclace also resulted in the increament of liquid (as shown in Figure $3 \mathrm{f}$ ). This proves that increasing periclace can promote liquid production and increase densification of the samples.

\section{Density and porosity measurements}

Figure 4 shows the variation of density and porosity as a function of periclace contents.

As can be observed (Figure 4a), the densities of the samples increase sharply as periclace addition to $5 \%$, and decrease slowly up to $15 \%$ addition. Meanwhile, the porosities of the samples decrease slowly as periclace addition to $5 \%$, and decrease sharply up to $15 \%$. The increased in the densitiy as periclace addition to $5 \%$ is most likely caused by the presence of dominant spinel phase as shown in Table 2. As shown in Figure 4a, the densities of the samples increase from 2.34 to $3.52 \mathrm{~g} \cdot \mathrm{cm}^{-3}$ as periclace content increased from 0 to $5 \%$. The density was slightly decreased as periclace content increased from 5 to $20 \%$ and reached the value of $3.21{\mathrm{~g} \cdot \mathrm{cm}^{-3}}^{-3}$ at periclace content of $30 \%$. The sharp increase of the density with increasing periclace content up to $5 \%$ was attributed to the increased amount of spinel phase, and slow decrease with increasing periclase up to $30 \%$ was considered to the increased amount of forsterite phase (Table 2). The change in density was most also likely due to decomposition of cordierite into spinel and forsterite, as displayed by the XRD results presented in Figures 1a-f. These results are in accordance with the results of others, who reported that, the density of spinel [54-55] and forsterite [56-57] phases are higher than cordierite [58]. In those previous studies, the density of spinel, and forsterite are 3.54 and $3.22 \mathrm{~g} \cdot \mathrm{cm}^{-3}$ respectively, while for cordierite, the reported value is $2.3{\mathrm{~g} \cdot \mathrm{cm}^{-3}}^{-3}$. These literature data are in aggrement with the findings in this present study, in which increased amount of periclace was found to enhance the formation of forsterite (Table 2), as discussed above.

The porosities of the samples decrease slowly as periclace addition to $5 \%$, and decrease sharply up to $10 \%$, and the density was slightly decreased as periclace content increased from 10 to $20 \%$ (Figure $4 \mathrm{~b}$ ). Further addition of periclace up to $25 \%$ shows a sharp decrease of porosity, but a small decrease of porosity up to $30 \%$ periclace addition. As can be seen in Figure $4 b$, the sharp decrease in porosity with increased periclace content from 20 to $25 \%$ observed in this study was attributed to enhanced formation of forsterite phase, and also the match between thermal expansion of spinel and forsterite, whereas addition of periclace in higher quantities (from 25 to $30 \%$ ) did not cause a remarkable decrease of porosity. It is obviously oberved that beyond this periclace content, porosity is slowly decreased, probably due to almost the same domination of phases such as spinel and forsterite, larger particles sizes covering surface of the samples, which is in accordance with the surface morphologies of the samples as seen in SEM results (Figures 3e-g). Moreover, the porosity was found to decrease as periclace content increased (Figure $4 b$ ), which is in agreement with the increase of

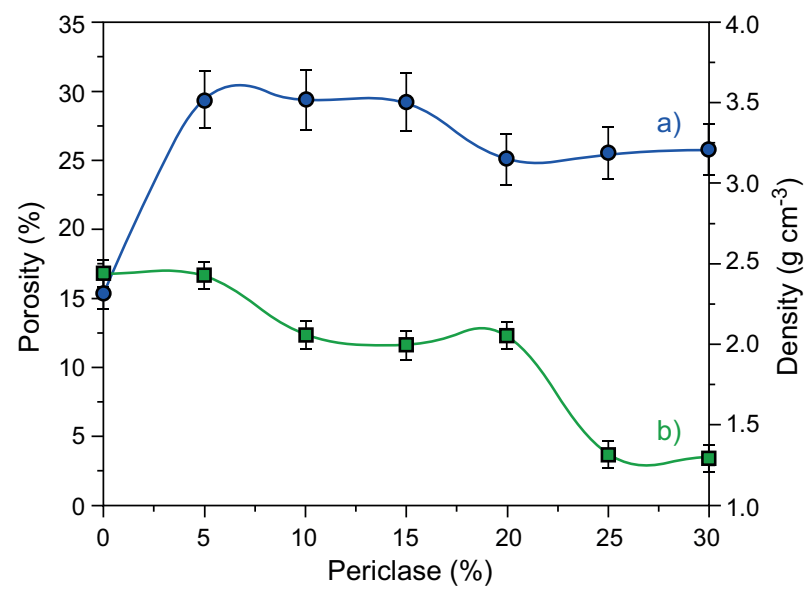

Figure 4. Density (a) and Porosity (b) of cordierite as a function of periclace addition. 
the amount of forsterite (Table 2). In addition, this is due to the high density of forsterite and spinel which caused density increased, and the high termal expansion coefficient of spinel and forsterite which made porosity decreased.

\section{Hardness and bending strength measurements}

Figure 5 represents the change of hardness and bending strength of the samples as a result of periclace addition.

The hardness (Figure 5a) increased sharply with increased periclace content from 0 to $5 \%$ and then decreased slightly with periclace addition from 5 to $30 \%$. This trend implies that the samples became more compact and denser as a result of increased amount of periclace, increasing the ability of the sample to overcome bending strength. Practically similar trend was observed for bernding strength (Figure 5b), in which sharply increased was found with periclace addition from 0 to $5 \%$, and relatively stable up to $30 \%$ periclace addition, as indicated by practicaly plat line (Fiure. 5b). This finding demonstrates that hardness and bending strength of the samples are compatible with the change of density and porosity observed in this study (Figures $4 a-b$ ). The role of density in determining hardness and porosity in determining in bending strength are in aggrement with the structure profile of the samples as revealed by the XRD results (Figures 1a-g). As previously discussed, increased amount of periclace led to formation of spinel and forsterite as the prime phases. These two phases are known to have higher densities than cordierite, confirming the role of density in enhancing the hardness of the samples, due to the change in phase composition of the samples. Other factors that control the hardness and bending strength are probably both the homogeneity and the distribution of the particles, which is in accordance with the surface morphology of the samples, as shown in Figures 3a-g.

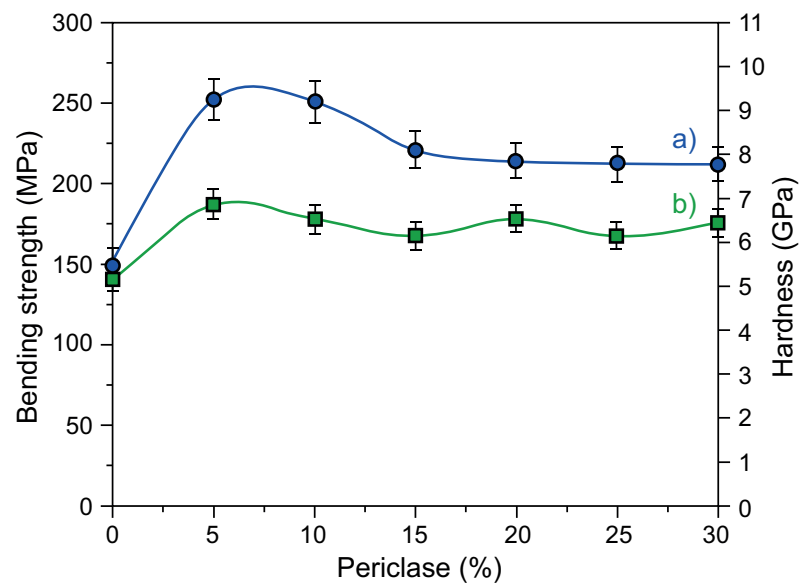

Figure 5. Hardness (a) and Bending strength (b) of cordierite as a function of periclace addition.

\section{Thermal expansion coefficient \\ measurements}

Figure 6 shows the change in thermal expansion coefficient of the samples as a function of periclace addition to cordierite.

The results show that the thermal expansion coefficient of the samples increased sharply from $2.4 \times 10^{-6} /{ }^{\circ} \mathrm{C}$ to $8.8 \times 10^{-6} /{ }^{\circ} \mathrm{C}$ as periclace addition increase from 0 to $5 \%$ and decrease from $8.8 \times 10^{-6} /{ }^{\circ} \mathrm{C}$ to $8.1 \times 10^{-6} /{ }^{\circ} \mathrm{C}$ when periclace increased from 5 to $10 \%$, and then slightly increased to the final value of $8.2 \times 10^{-6} /{ }^{\circ} \mathrm{C}$ at periclace content up to $30 \%$. It can be summarised that, as the periclace content increased, the coefficient of thermal expansion increased, most probably due to the decreased amount of cordierite and increased amount of spinel and forsterite (Table 2). The trend observed in this study shows that the change of thermal expansion coefficient is given by the coefficient of thermal expansion of each phase presents in the sample, volume fraction of the phase and porosity as described in the previous studies. They observed that thermal expansion coefficient has a direct relationship with the amount of phase and an inverse relationship with the amount of the porosity [59, 60], with the equation: $\alpha=\left(\alpha_{1} v_{1}+\alpha_{2} v_{2}+\ldots+\alpha_{n} v_{n}\right)(1-P)$, where $\alpha_{1}, \alpha_{2}$ and $\alpha_{n}$ are the thermal expansion coefficients of each raw material, $v_{1}, v_{2}$ and $v_{n}$ are the volume fractions, and $P$ is the porosity. It can be seen that coefficient of thermal expansion of spinel, and forsterite are higher than cordierite, which are in agreement with the results described in previous study [58]. More specifically, it was reported that the coefficient of thermal expansion of spinel [14], and forsterite [61] are $9.17 \times$ $\times 10^{-6} /{ }^{\circ} \mathrm{C}$ and $9.2 \times 10^{-6} /{ }^{\circ} \mathrm{C}$, respectively, and thermal expansion coefficient of cordierite is $2.65 \times 10^{-6} /{ }^{\circ} \mathrm{C}$ [14]. In accordance with the above values reported by others, it is then clear that increased thermal expansion coefficient of the samples investigated in this study is most likely associated with domination of spinel and forsterite phases as confirmed by XRD results (Table 2), also decreased porosity (Figure $4 b$ ).

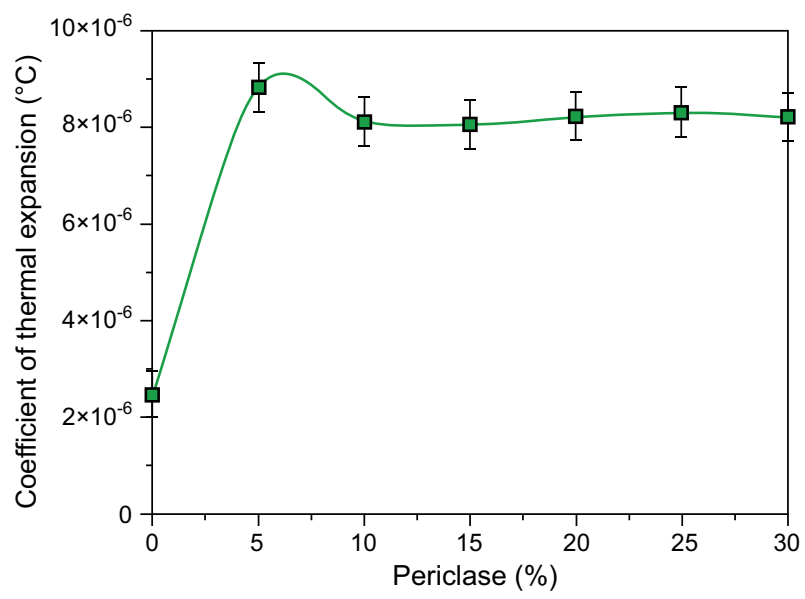

Figure 6. Coefficient of thermal expansion of cordierite as a function of periclace addition. 


\section{CONCLUSIONS}

This study shows that refractory cordierite was successfully produced form rice husk silica as renewable raw materials and modified by addition of varied amounts of periclace, resulted in enhanced transformation of cordierite into forsterite and spinel. This transformation led to significant change of the characteristics of the samples, include increased density, hardness, bending strength, thermal expansion coefficient, and followed by decreased porosity. Furthermore, the sample with periclace addition of $30 \%$ consists of $60.5 \%$ forsterite, $30.6 \%$ spinel, and $8.9 \%$ periclace. Based on these characteristics, it is evident that refractory cordierite of the modified samples with periclace exist as dense form with the characteristics suitable for mechanical applications, such as abrasive devices.

\section{Acknowledments}

The authors wish to thank and appreciate The Directorate of Higher Education, The Ministry of Research, Technology, and Higher Education, Republic of Indonesia for research funding provided through Hibah Competence Research Grant Batch II No: 382/ UN26.21/KU/2017 Program in 2017.

\section{REFERENCES}

1. Takahashi J., Natsuisaka M., Shimada S. (2002): Fabrication of cordierite-mullite ceramic composites with differently shaped mullite grains. Journal of the European Ceramic Society, 22(4), 479-485. doi: 10.1016/S0955-2219 (01)00312-0

2. Marghussian V. K., Balazadegan O. U., Eftekhari-Yekta B. (2009): Crystallization behaviour, microstructure and mechanical properties of cordierite-mullite glass ceramics. Journal of Alloys and Compounds, 484(1-2), 902-906. doi: 10.1016/j.jallcom.2009.05.080

3. Hung C. M. (2010): Cordierite-supported Pt-Pd-Rh ternary composite for selective catalytic oxidation of ammonia. Powder Technology, 200(1-2), 78-83. doi: 10.1016/j.powtec. 2010.02.014

4. Labrincha J. A., Albuquerque C. M., Ferreira J. M., Ribeiro M. J. (2006): Electrical characterisation of cordierite bodies containing Al-rich anodising sludge. Journal of the European Ceramic Society, 26(4-5), 825-830. doi: 10.1016/j. jeurceramsoc.2005.07.004

5. Ribeiro M. J., Blackburn S., Ferreira J. M., Labrincha J. A. (2006): Extrusion of alumina and cordierite-based tubes containing Al-rich anodising sludge. Journal of the European Ceramic Society, 26(4-5), 817-823. doi: 10.1016/ j.jeurceramsoc.2005.07.040

6. Laokul P., Maensiri S. (2006): Synthesis, characterization and sintering behavior of nanocrystalline cordierite ceramics. Advances in Science and Technology, 45, 242-247. doi: 10.4028/www.scientific.net/AST.45.242
7. Gonzalez-Velasco J. R., Gutierrez-Ortiz M. A., Ferret R., Aranzabal A., Botas J. A. (1999): Synthesis of cordierite monolithic honeycomb by solid state reaction of precursor oxides. Journal of Materials Science, 34(9). doi: 10.1023/A:1004578819314

8. Evans D. L., Fischer G. R., Geiger J. E., Martin F. W. (1980): Thermal expansions and chemical modifications of cordierite. Journal of the American Ceramic Society, 63 (11-12), 629-634. doi: 10.1111/j.1151-2916.1980.tb09850.x

9. Janackovic D. J., Jokanovic V., Kostic-Gvozdenovic L. J., Zec S., Uskokovic D. (1997): Synthesis and formation mechanism of submicrometre spherical cordierite powders by ultrasonic spray pyrolysis. Journal of Materials Science, 32(1), 163-168. doi: 10.1023/A:1018595720313

10. Sarkar G., Kulkarni K., Lam H. M. (2003): A study of the factors affecting dielectric properties of sol-gel derived cordierite to be used in a plasma display panel. Journal of Materials Science, 38(8), 1803-1807. doi: 10.1023/A: 1023248331294

11. Wang, S., \& Zhou, H. (2004). Sintering characteristics and crystallization for sol-gel-derived powders for lowdielectric and low-temperature sintering ceramics. Journal of Materials Science: Materials in Electronics, 15(1), 55-59. doi: 10.1023/A:1026249206524

12. Rattanavadi S. (2016): Cordierite Composites Using New Source of Waste; Sludge Cake from Cosmetic Industry in Thailand. In Key Engineering Materials (Vol. 675, pp. 490-493). Trans Tech Publications. doi: 10.4028/www. scientific.net/KEM.675-676.490

13. Ewais E. M. M., Ahmed Y. M. Z., Ameen A. M. M. (2009): Preparation of porous cordierite ceramic using a silica secondary resource (silica fumes) for dust filtration purposes. Journal of Ceramic Processing Research, 10(6), 721-728.

14. Acimovic Z., Pavlovic L., Trumbulovic L., Andric L., Stamatovic M. (2003): Synthesis and characterization of the cordierite ceramics from nonstandard raw materials for application in foundry. Materials Letters, 57(18), 26512656. doi: 10.1016/S0167-577X(02)01345-9

15. Benhammou A., El Hafiane Y., Abourriche A., Abouliatim Y., Nibou L., Yaacoubi A., Tessier-Doyen N., Smith A.,Tanouti, B. (2014): Effects of oil shale addition and sintering cycle on the microstructure and mechanical properties of porous cordierite-ceramic. Ceramics International, 40(7), 8937-8944. doi: 10.1016/j.ceramint.2014. 02.105

16. Njoya D., Elimbi A., Fouejio D., Hajjaji M. (2016): Effects of two mixtures of kaolin-talc-bauxite and firing temperatures on the characteristics of cordierite-based ceramics. Journal of Building Engineering, 8, 99-106. doi: 10. 1016/j.jobe.2016.10.004

17. Sembiring S., Simanjuntak W., Situmeang R., Riyanto A., Sebayang K. (2016): Preparation of refractory cordierite using amorphous rice husk silica for thermal insulation purposes. Ceramics International, 42(7), 8431-8437. doi: 10.1016/j.ceramint.2016.02.062

18. Zhu P., Wang L. Y., Hong D., Zhou M. (2012): A study of cordierite ceramics synthesis from serpentine tailing and kaolin tailing. Science of Sintering, 44(2), 129-134. doi: 10.2298/SOS1202129Z

19. Amista P., Cesari M., Montenero A., Gnappi G., Lan L. (1995): Crystallization behaviour in the system $\mathrm{MgO}$ $-\mathrm{Al}_{2} \mathrm{O}_{3}-\mathrm{SiO}_{2}$. Journal of Non-crystalline Solids, 192, 529-533. doi: 10.1016/0022-3093(95)00451-3 
20. Hwang S. P., Wu J. M. (2001): Effect of Composition on Microstructural Development in $\mathrm{MgO}-\mathrm{Al}_{2} \mathrm{O}_{3}-\mathrm{SiO}_{2}$ GlassCeramics. Journal of the American ceramic Society, 84(5), 1108-1112. doi: 10.1111/j.1151-2916.2001.tb00797.x

21. Banjuraizah J., Mohamad H., Ahmad Z. A. (2011): Densification and crystallization of nonstoichiometric cordierite glass with excess $\mathrm{MgO}$ synthesized from kaolin and talc. Journal of the American Ceramic Society, 94(3), 687-694. doi: 10.1111/j.1551-2916.2010.04144.x

22. Li Y., Cheng X., Zhang R., Wang Y., Zhang H. (2015): Effect of Excess $\mathrm{MgO}$ on the Properties of Cordierite Ceramic Sintered by Solid-State Method. International Journal of Applied Ceramic Technology, 12(2), 443-450. doi: 10.1111/ijac.12174

23. Xiang R., Li Y., Li S., Li Y., Sang S. (2016): Effect of Excess Magnesia on the Preparation of Cordierite Based on Waste Foundry Sand. International Journal of Applied Ceramic Technology, 13(3), 603-608. doi: 10.1111/ijac.12509

24. Sembiring S., Simanjuntak W., Situmeang R., Riyanto A., Karo-Karo P. (2017): Effect of alumina addition on the phase transformation and crystallisation properties of refractory cordierite prepared from amorphous rice husk silica. Journal of Asian Ceramic Societies, 5(2), 186-192. doi: 10.1016/j.jascer.2017.04.005

25. Li Y., Qian H., Cheng X., Zhang R., Zhang H. (2014): Fabrication of dense cordierite ceramic through reducing $\mathrm{Al}_{2} \mathrm{O}_{3}$ mole ratio. Materials Letters, 116, 262-264. doi: 10.1016/j.matlet.2013.11.011

26. Abdel-Hameed S. A., Bakr I. M. (2007): Effect of alumina on ceramic properties of cordierite glass-ceramic from basalt rock. Journal of the European Ceramic Society, 27 (2-3), 1893-1897. doi: 10.1016/j.jeurceramsoc.2006.05.016

27. Rafiee E., Shahebrahimi S., Feyzi M., Shaterzadeh, M. (2012): Optimization of synthesis and characterization of nanosilica produced from rice husk (a common waste material). International Nano Letters, 2(1), 29. doi: 10.1186 / 2228-5326-2-29

28. Ugheoke B. I., Mamat O. (2012): A novel method for high volume production of nano silica from rice husk: Process development and product characteristics. International Journal of Materials Engineering Innovation, 3(2), 139-155.

29. Sun L., Gong K. (2001): Silicon-based materials from rice husks and their applications. Industrial \& Engineering Chemistry Research, 40(25), 5861-5877. doi:10.1021/ ie $010284 \mathrm{~b}$

30. Chandrasekhar S. A. T. H. Y., Satyanarayana K. G., Pramada P. N., Raghavan P., Gupta, T. N. (2003): Review processing, properties and applications of reactive silica from rice husk - an overview. Journal of Materials Science, 38(15), 31593168. doi: 10.1023/A:1025157114800

31. Maiti S., Banerjee P., Purakayastha S., Ghosh B. (2008): Silicon-doped carbon semiconductor from rice husk char. Materials Chemistry and Physics, 109(1), 169-173. doi: 10.1016/j.matchemphys.2007.11.011

32. Singh S. K., Mohanty B. C., Basu S. (2002): Synthesis of $\mathrm{SiC}$ from rice husk in a plasma reactor. Bulletin of Materials Science, 25(6), 561-563. doi: 10.1007/BF02710551

33. Karmakar B., Kundu P., Jana S., Dwivedi R. N. (2002): Crystallization Kinetics and Mechanism of Low-Expansion Lithium Aluminosilicate Glass-Ceramics by Dilatometry. Journal of the American Ceramic Society, 85(10), 2572-2574. doi: 10.1111/j.1151-2916.2002.tb00498.x
34. Chatterjee M., Naskar M. K. (2006): Sol-gel synthesis of lithium aluminum silicate powders: the effect of silica source. Ceramics international, 32(6), 623-632. doi: 10. 1016/j.ceramint.2005.03.033

35. Naskar M. K., Chatterjee, M. (2004): A novel process for the synthesis of cordierite $\left(\mathrm{Mg}_{2} \mathrm{Al}_{4} \mathrm{Si}_{5} \mathrm{O}_{18}\right)$ powders from rice husk ash and other sources of silica and their comparative study. Journal of the European Ceramic Society, 24(13), 3499-3508. doi: 10.1016/j.jeurceramsoc.2003.11.029

36. Serra M. F., Conconi M. S., Gauna M. R., Suárez G., Aglietti E. F., Rendtorff N. M. (2016): Mullite $\left(3 \mathrm{Al}_{2} \mathrm{O}_{3}\right.$. $2 \mathrm{SiO}_{2}$ ) ceramics obtained by reaction sintering of rice husk ash and alumina, phase evolution, sintering and microstructure. Journal of Asian Ceramic Societies, 4(1), 61-67. doi: 10.1016/j.jascer.2015.11.003

37. Amutha K., Ravibaskar R., Sivakumar G. (2010): Extraction, synthesis and characterization of nanosilica from rice husk ash. International Journal of Nanotechnology and applications, 4(1), 61-66.

38. Simanjuntak W., Sembiring S., Pandiangan K.D., Syani F., Situmeang R.T.M. (2016): The Use of Liquid Smoke as a Substitute for Nitric Acid for Extraction of Amorphous silica from Rice husk through Sol-Gel Route. Oriental Journal of Chemistry, 32(4), 2079-2085. doi: 10.13005/ ojc/320435

39. Sembiring S. (2011): Synthesis and characterization of rice husk silica based borosilicate $\left(\mathrm{B}_{2} \mathrm{SiO}_{4}\right)$ ceramics by sol-gel routes. Indonesian Journal of Chemistry, 11(1), 85-89.

40. Simanjuntak W., Sembiring S., Sebayang K. (2012): Effect of pyrolysis temperatures on composition and electrical conductivity of carbosil prepared from rice husk. Indonesian Journal of Chemistry, 12(2), 119-125.

41. Simanjuntak W., Sembiring S., Manurung P., Situmeang R., Low I. M. (2013): Characteristics of aluminosilicates prepared from rice husk silica and aluminum metal. Ceramics International, 39(8), 9369-9375. doi: 10.1016/j.ceramint.2013.04.112

42. Sembiring S., Simanjuntak W. (2013). X-ray diffraction phase analyses of mullite derived from rice husk silica. Makara Journal of Science, 77-82. doi: 10.7454/mss. v16i2.1399

43. Sembiring S., Simanjuntak W., Manurung P., Asmi D., Low, I. M. (2014): Synthesis and characterisation of gelderived mullite precursors from rice husk silica. Ceramics International, 40(5), 7067-7072. doi: 10.1016/j.ceramint. 2013.12.038

44. Simanjuntak W., Sembiring S. (2011): The use of the Rietveld method to study the phase composition of cordierite $\left(\mathrm{Mg}_{2} \mathrm{Al}_{4} \mathrm{Si}_{5} \mathrm{O}_{18}\right)$ ceramics prepared from rice husk silica. Makara Journal of Science, 11(1), 97-100. doi: 10.7454/mss.v15i1.886

45. Sembiring S., Riyanto A., Simanjuntak W., Situmeang R. (2017): Effect of $\mathrm{MgO}-\mathrm{SiO}_{2}$ Ratio on the Forsterite $\left(\mathrm{Mg}_{2} \mathrm{SiO}_{4}\right)$ Precursors Characteristics Derived from Amorphous Rice Husk Silica. Oriental Journal of Chemistry, 33(4), 1828-1836. doi: 10.13005/ojc/330427

46. ADE Program XRD Pattern Processing PC (1997). Material Data Inc (MDI), Livermore, CA.

47. Hunter B. A. (1997). Software Rietica for 95/98 Window $N T$. Version 1(70), Q10.

48. Powder Diffraction File (Type PDF-2) (1997). Diffraction Data for XRD Identification. International Centre for Diffraction data, PA USA. 
49. Downs R. T., Hall-Wallace M. (2003): The American Mineralogist crystal structure database. American Mineralogist, 88(1), 247-250.

50. Australian Standard (1989). Refractories and Refractory Material Physical Test Methods: The Determination of Density, Porosity and Water Adsorption, 1-4, 1774.

51. Wilding M. C., Benmore C. J., Tangeman J. A., Sampath S. (2004): Coordination changes in magnesium silicate glasses. EPL (Europhysics Letters), 67(2), 212. doi: 10.1209/epl/i2003-10286-8

52. Petrović R., Janaćković D., Zec S., Drmanić S., KostićGvozdenović L. (2003): Crystallization behavior of alkoxyderived cordierite gels. Journal of sol-gel science and technology, 28(1), 111-118. doi: 10.1023/A:1025649406466

53. Kisi E. H. (1994): Rietveld analysis of powder diffraction patterns. In Materials Forum (Vol. 18, pp. 135-155).

54. Padmaraj O., Venkateswarlu M., Satyanarayana N. (2015): Structural, electrical and dielectric properties of spinel type $\mathrm{MgAl}_{2} \mathrm{O}_{4}$ nanocrystalline ceramic particles synthesized by the gel-combustion method. Ceramics International, 41(2), 3178-3185. doi: 10.1016/j.ceramint.2014.10.169

55. Ganesh I. (2011): Fabrication of magnesium aluminate $\left(\mathrm{MgAl}_{2} \mathrm{O}_{4}\right)$ spinel foams. Ceramics International, 37(7), 2237-2245. doi: 10.1016/j.ceramint.2011.03.068
56. Ghomi H., Jaberzadeh M., Fathi M. H. (2011): Novel fabrication of forsterite scaffold with improved mechanical properties. Journal of Alloys and Compounds, 509(5), L63-L68. doi: 10.1016/j.jallcom.2010.10.106

57. Kudoh Y., Takéuchi Y. (1985): The crystal structure of forsterite $\mathrm{Mg}_{2} \mathrm{SiO}_{4}$ under high pressure up to $149 \mathrm{~kb}$. Zeitschrift für Kristallographie-Crystalline Materials, 171(1-4), 291-302. doi: 10.1524/zkri.1985.171.14.291

58. Charles A.H. (2001). Handbook of ceramic glasses and diamonds, Mc Graw Hills, Company Inc, USA.

59. Ono T., Matsumaru K., Juárez-Ramírez I., Torres-Martínez L. M., Ishizaki K. (2009): Development of Porous Material with High Young's Modulus and Low Thermal Expansion Coefficient in SiC-Vitrified Bonding Material-LiAlSiO System. Materials Science Forum, 620, 715-718. doi: 10.4028/www.scientific.net/MSF.620-622.715

60. Plešingerová B., Klapáč M., Kovalčíková, M. (2002): Moisture expansion of porous biscuit bodies-reason of glaze cracking. Ceramics- Silikáty, 46(4), 159-165.

61. Ye Y., Schwering R. A., Smyth J. R. (2009): Effects of hydration on thermal expansion of forsterite, wadsleyite, and ringwoodite at ambient pressure. American Mineralogist, 94(7), 899-904. doi: 10.2138/am.2009.3122 